\title{
Bioavailability Analysis of Oxalate and Mineral Content in Selected Edible Mushrooms
}

\section{Nile $\mathrm{SH}^{*}$ and Park SW}

Department of Molecular Biotechnology, College of Life and Environmental Sciences, Konkuk University, Seoul-143-701, South Korea

*Corresponding author: Nile SH, Biotechnology Research Laboratory, School of Life Sciences, Swami Ramanand Teerth Marathwada University, Nanded-431606, Maharashtra, India, Tel: 919326363750, 919326363750; E-mail: nileshivraj@gmail.com

Rec Date: Feb 27, 2014, Acc Date: Apr 26, 2014, Pub Date: Apr 28, 2014

Copyright: (C) 2014 Nile SH, et al. This is an open-access article distributed under the terms of the Creative Commons Attribution License, which permits unrestricted use, distribution, and reproduction in any medium, provided the original author and source are credited.

\begin{abstract}
Total, soluble, insoluble oxalate and mineral content of 20 edible mushrooms were measured using spectroscopic and enzymatic methods. Total oxalate content ranged from 45 (Hericium erinaceus) to 104 (Morchella conica), $\mathrm{mg} / 100 \mathrm{~g}$ dry matter (DM), while the soluble oxalate levels ranged from 34 (Lactaius delicious) to 65 (Phellinus florida) $\mathrm{mg} / 100 \mathrm{~g}$ DM but not detected in Hericium erinaceus, Sparassis crispa, Geastrum arinarius, Boletus edulis, Helvella crispa, and Ganoderma lucidum respectively and very low in Lactaius delicious (34), Russula brevepis (35), and Cantharellus clavatus (37) $\mathrm{mg} / 100 \mathrm{~g} \mathrm{DM}$. The $\mathrm{Ca}, \mathrm{P}, \mathrm{K}$ and $\mathrm{Mg}$ content showed range of $1.35-12.56 \mathrm{mg} / \mathrm{g}$ for Ca, 1.22-3.82 $\mathrm{mg} / \mathrm{g}$ for $\mathrm{P}, 15.4-25.4 \mathrm{mg} / \mathrm{g}$ for $\mathrm{K}$ and $1.19-4.71 \mathrm{mg} / \mathrm{g}$ for $\mathrm{Mg}$. Overall, the percentage of soluble oxalate content of the selected mushrooms ranged from 34 to $65 \%$ of the total oxalate content which suggests that, the selected edible mushrooms presents no risk to people liable to kidney stone formation while other foods like some spices and vegetables can supply significant amounts of soluble oxalates and therefore should be used in moderation as good vegetable, which might be important for human nutrition.
\end{abstract}

Keywords: Oxalates; Minerals; Vegetables; Mushrooms

\section{Introduction}

Mushrooms have long been valued as highly tasty and nutritional foods throughout the world and appreciated for their flavor and texture as vegetables. Mushrooms provide a wealth of protein, fiber, vitamins, and minerals. On average, dried mushrooms contain $\sim 22 \%$ protein, which includes most of the essential amino acids, $\sim 5 \%$ fat, mostly in the form of linoleic acid (the essential fatty acid not synthesized in the human body), $\sim 63 \%$ carbohydrates including fiber, and $\sim 10 \%$ minerals as ash and are a good source of several vitamins including thiamin, riboflavin, niacin, and biotin [1,2]. Mushrooms probably contain every mineral present in their growth substrate including substantial quantities of phosphorous and potassium, lesser amounts of calcium and iron and appear to be an excellent source of vitamins especially thiamine (B1), riboflavin (B2), niacin, biotin and ascorbic acid (Vitamin $\mathrm{C}$ ). Vitamins $\mathrm{A}$ and $\mathrm{D}$ are relatively uncommon although several species contain detectable amounts of $\beta$ carotene and ergosterol which converts to active vitamin D when exposed to ultraviolet irradiation [3]. The crude fat in mushrooms contains all the main classes of lipid compounds including free fatty acids, mono, di and triglycerides, sterols, sterol esters and phospholipids. The calcium oxalate is a substance so generally found in the fungi that it is quite unnecessary to enumerate the instances of its occurrence and the walls of fungi like Agaricus compestris. This calcium oxalate was so encrusted in this mushroom that the mycelia appeared chalky coloured. The mycelia of $A$. campestrisas having a more or less complete covering of needle-like crystals due to deposition of these calcium oxalates [4,5]. Similar needle-like crystals were observed on the outer walls of the hyphae of Agaricus bisporus. However, there appear to be few reports on the oxalate content of the edible parts of commonly consumed mushrooms. Fungi, such as Aspergillus niger, Penicillium, Mucor, Boletus sulfurens, and
Sclerotinia, can synthesize oxalic acid up to $4-5 \mathrm{~g} / 100 \mathrm{~g}$ dry weight (DW) in isolated cultivation, in foodstuffs and on the surface of forages [6]. In a summary of the world literature, it is highlighted that the lack of data available on the oxalate content of common foods, including fungi and many high oxalate containing foods contained both soluble and insoluble oxalates [7]. Oxalates exist in two different forms in plant foods, water-soluble salts with sodium, potassium and ammonium ions, and insoluble salts with calcium, magnesium and iron ions, rendering these minerals unavailable to animals [4,5]. After consumption by humans, insoluble oxalates are excreted in the feces. Soluble oxalates are able to bind to calcium and other minerals under acidic to near-neutral conditions in the intestine making these minerals unavailable. It has been reported that after ingestion of food only $2-12 \%$ oxalate out of the total oxalate eaten is absorbed, and the remaining free oxalate combines with calcium to form calcium oxalate in the intestinal lumen, making calcium unavailable for absorption [8]. There are two main effects of oxalate on human health: first, oxalate can form insoluble salts in the digestive tract by binding to cations such as calcium, iron and magnesium, decreasing the bioavailability of these essential minerals [9]. Secondly, soluble oxalate, once absorbed into the body has to be excreted in the urine. In this process oxalates can bind to calcium and form insoluble calcium oxalate, which then accumulates in the kidneys. It has been estimated that approximately $75 \%$ of all kidney stones are composed of this calcium oxalate [10]. The diet plays an important role in the incidence of stone formation; avoiding the excessive consumption of high-oxalate containing foods and consuming calcium containing dairy foodsare logical ways to limit calcium oxalate stone formation in the kidney $[11,12]$. The oxalate content of food can vary considerably between plants of the same species, due to differences in climate, soil quality, state of ripeness, or even which part of the plant is analyzed. Variations also may be caused by the different methods used for measuring oxalate in food [13]. The objective of this study was to use the methods to measure the total oxalate content and soluble oxalate content of common edible 
mushrooms that are regularly used as food and are sometimes taken in larger amounts, so that reliable advice can be given to people who have to consider the possible adverse effects of consuming mushrooms which may contain high levels of available oxalates.

\section{Materials and Methods}

\section{Materials}

Twenty species of mushroom fruiting bodies collected from natural growth in different geographic locations of India, (Maharashtra, Kerala, Himachal Pradesh, Nagaland and Madhya Pradesh) at different time interval (June, July, August, September and October), during the year, 2013. These species were taxonomically identified by botanist and deposited in department herbarium (Voucher No $\mathrm{KU} / \mathrm{BT} / \mathrm{P} / \mathrm{SN} /$ Mushrooms).

\section{Sample preparation}

All procured and selected varieties of edible mushrooms were cleaned to remove any residual compost, and soil. The mushrooms were trimmed and peeled to remove any non-edible portions. The mushrooms were subsequently air-dried in the oven at $45^{\circ} \mathrm{C}$ for about $5 \mathrm{~h}$. All of the dried mushrooms were ground to fine powder (ca. 1 $\mathrm{mm}$ size) and stored in airtight plastic bags in desiccators at room temperature for further analysis. Ten grams of each dried mushroom sample was mixed with $100 \mathrm{~mL}$ of boiled water for $5 \mathrm{~min}$. Samples were stirred for $15 \mathrm{~min}$ for effective extraction and centrifuged at $5000 \mathrm{~g}$ for $15 \mathrm{~min}$. Supernatants were referred to as mushroom water extract (MWE), and stored at $4^{\circ} \mathrm{C}$ until the completion of the analysis. The yield of extraction was expressed as percent on a dry weight basis $[14,15]$.

\section{Moisture content}

The moisture content of each sample of dried edible mushrooms was determined by drying them over night in an oven (Bio-Era Equipments, Mumbai, India) set at $125^{\circ} \mathrm{C}$ to a constant weight. The sample with watch glass was cooled at room temperature in desiccators before weighing, the weight loss in sample regarded as moisture content. All determinations were performed in triplicate [16].

\section{Determination of total and soluble oxalate}

The measurement of total and soluble oxalate was performed according previously outlined methods; the oxalic acid peak was identified by comparing the retention time with an oxalate standard solution and by spiking the sample with a known quantity of oxalic acid standard solution. The content of insoluble oxalate was calculated by subtracting the amount of soluble oxalate from the total oxalate content. All determinations were performed in triplicates $[4,8]$.

\section{Enzymatic oxalate assay}

The extracted mushroom samples were analyzed in duplicate for oxalate by an enzymatic method using an oxalate kit (Sigma-Aldrich. Mumbai). This method is based on oxidation of oxalate by oxalate oxidase, followed by detection of hydrogen peroxide $\left(\mathrm{H}_{2} \mathrm{O}_{2}\right)$ produced during the reaction. Lyophilized (control) urine samples having predetermined oxalate concentrations of between 20 and $30 \mathrm{mg} / \mathrm{L}$ were analyzed with each assay for quality control purposes [17].

\section{Mineral analysis}

The minerals, Calcium (Ca), Phosphorus (P), Potassium (K), and Magnesium $(\mathrm{Mg})$, were chosen for analysis because of their presumed association with oxalate content in food. The fruiting bodies of mushrooms were dry-ashed at $490^{\circ} \mathrm{C}$, and then the ash was digested with aqua-regia (mixture of one part of nitric acid and three parts of hydrochloric acid). The mineral concentrations in the digests were assayed using inductive coupled argon plasma emission techniques, with a Thermo Jarrell-Ash ICP/IRIS with a charged injection device $[18,19]$. The Ca concentrations of mushrooms were determined by blending $5 \mathrm{~g}$ of the mushrooms fruiting body extract in $100 \mathrm{~mL}$ of $\mathrm{HCl}$ (3 N). The supernatant was analyzed using atomic absorption spectrophotometer (Perkin-Elmer-2380) in lanthanum chloride [20].

\section{Results and Discussion}

The result for yield of extraction was expressed in percent on a dry weight basis, which was in average found to be $10.35 \%$ (g/100 gm of dry mushroom). The mean residual moisture content of the twenty edible mushrooms was $88.7 \%$, which were typical for dietary foods (Table 1) [17]. The total oxalate content of the edible mushrooms measured in this study ranged from 45 to $104 \mathrm{mg}(\mathrm{mg} / 100 \mathrm{gm})$ on dry matter basis, while the soluble oxalate levels ranged from 34 to 65 $\mathrm{mg} / 100 \mathrm{~g} \mathrm{DM}$ and the soluble oxalate not detected in Hericium erinaceus, Sparassis crispa, Geastrum arinarius, Boletus edulis, Helvella crispa, and Ganoderma lucidum and very low levels were found in Lactaius delicious (34), Russula brevepis (35), and Cantharellus clavatus (37) mg/100g DM. The mushrooms Phellinus floriada (65) and Morchella conica (60) contained the highest proportion of soluble oxalate $\mathrm{mg} / 100 \mathrm{~g} \mathrm{DM}$ of the total oxalate content followed by Morchella conica (104), Cantharellus cibarius (96), Phellinus rimosus (94) and Auricularia polytricha (92) (mg/100g DM) and all other mushrooms contained soluble oxalates which ranged from 35 to $65 \%$ of the total oxalates ( 45 to $89 \%$ ), presented in Table 2, respectively.

Earlier studies showed that the mean dry matter content of the raw mushrooms was $7.91 \%$, while the dry matter content of the cooked mushrooms was $9.96 \%$, as compared to other common oxalate containing foods the levels of oxalates in cultivated mushrooms are relatively low [4,5]. The $\mathrm{Ca}, \mathrm{P}, \mathrm{K}$, and $\mathrm{Mg}$ contents of 20 samples of edible mushrooms are presented in (Table 3 ). The analysis of the four minerals ranges of $1.35-12.56 \mathrm{mg} / \mathrm{g}$ for $\mathrm{Ca}, 1.22-3.82 \mathrm{mg} / \mathrm{g}$ for $\mathrm{P}$, 15.4-25.4 mg/g for $\mathrm{K}$, and 1.19-4.71 mg/g for Mg. Morchella conica had the highest insoluble and total oxalate contents of any of the cultivars tested, and it also had the highest Ca content, in contrast, Hericium erinaceus and Boletus edulis had the lowest insoluble and total oxalate contents and the lowest Ca content. The other cultivars were intermediate for these values as well as for the other three minerals analyzed (Table 2). These results indicated that, among genetically different cultivars grown in the same general region under the same environmental conditions, the variation in total oxalate was substantial [21,22]. There was a correlation between total oxalate content and $\mathrm{Ca}$ content in the studied mushrooms, suggesting that as oxalate increases, Ca binding increases as result obtained in the case of Morchella conica in which the calcium concentration is high (12.56 $\mathrm{mg} / \mathrm{g}$ ), which correlate with high oxalate content $(104 \mathrm{mg} / \mathrm{g})$. Some of the other cultivars showed much lower total oxalate and Ca content, such as Hericium erinaceus and Boletus edulis showed 45 and $48 \mathrm{mg} / \mathrm{g}$ oxalate content and $1.35 \mathrm{mg} / \mathrm{g}$ Ca content, respectively (Table 3), suggesting that these, or other lower $\mathrm{Ca}$ and oxalate containing 
Citation: Nile SH and Park SW (2014) Bioavailability Analysis of Oxalate and Mineral Content in Selected Edible Mushrooms. J Nutr Disorders

Page 3 of 6

cultivars, need to be studied for their suitability in making food products. The critical factor in a food's effect on urinary oxalate is not the total oxalate but the amount of oxalate that is absorbed from that food and ultimately excreted in the urine.

\begin{tabular}{|c|c|c|c|}
\hline Mushroom Samples & Range(n) & Moisture (g/100gm) & $\%$ Yield \\
\hline H. erinaceus & 3 & $92 \pm 1.2$ & 12 \\
\hline S. crispa & 3 & $90 \pm 0.9$ & 10 \\
\hline C. cibarius & 3 & $93 \pm 1.1$ & 8 \\
\hline L. squarrulosus & 3 & $86 \pm 1.4$ & 12 \\
\hline H. repandum & 3 & $90 \pm 0.6$ & 9 \\
\hline P. sajorcaju & 3 & $85 \pm 0.6$ & 13 \\
\hline G. arinarius & 3 & $88 \pm 1.3$ & 14 \\
\hline L. sanguifluus & 3 & $92 \pm 1.3$ & 15 \\
\hline A. polytricha & 3 & $84 \pm 1.1$ & 10 \\
\hline R. brevepis & 3 & $89 \pm 0.7$ & 8 \\
\hline M. conica & 3 & $85 \pm 0.5$ & 14 \\
\hline B. edulis & 3 & $90 \pm 0.8$ & 6 \\
\hline L. deliciosus & 3 & $87 \pm 1.2$ & 5 \\
\hline C. clavatus & 3 & $86 \pm 0.5$ & 8 \\
\hline H. crispa & 3 & $94 \pm 1.1$ & 6 \\
\hline A. bisporus & 3 & $89 \pm 1.3$ & 9 \\
\hline P. djamor & 3 & $92 \pm 1.6$ & 14 \\
\hline G. lucidum & 3 & $84 \pm 1.4$ & 12 \\
\hline P. rimosus & 3 & $90 \pm 1.2$ & 9 \\
\hline P. florida & 3 & $88 \pm 1.1$ & 13 \\
\hline
\end{tabular}

Table 1: Moisture content and percent yield of mushroom in water extracts

It has generally been assumed that Ca-oxalate is not significantly absorbed in humans because it is virtually insoluble in aqueous solutions, $\sim 1 \mathrm{mg} / 100 \mathrm{~mL}$ [23]. In fact, diet therapy for Ca-oxalate kidney stones recommends the inclusion of high-Ca food in every meal to bind food oxalate in order to reduce its absorption [24]. However, previously it was reported that $10 \%$ of a load of Ca-oxalate was absorbed by healthy humans and passive uptake of Ca-oxalate as an intact molecule, at least in rats; less than $2 \%$ of the load was absorbed via Ca-oxalate binding pathway $[25,26]$. Even if Ca-oxalate is poorly absorbed, not all oxalate in mushroom is Ca bound and oxalate not bound to $\mathrm{Ca}$ is assumed to be bound to potassium and/or sodium and is referred to as soluble oxalate, as these salts have solubility in the range of $2.5-16.7 \mathrm{~g} / 100 \mathrm{~mL}$ [27]. Absorption of oxalate from $\mathrm{Na}$ oxalate solutions has been reported to vary from 2 to $20 \%$ in healthy humans without gastrointestinal disease [28]. Oxalate also forms insoluble salts with magnesium, iron, and copper; these salts have solubility's only from 3 to $22 \mathrm{mg} / 100 \mathrm{~mL}$ [20]. Despite earlier observations of calcium oxalate crystals occurring on hyphae and the levels of oxalates found in the edible parts of cultivated mushrooms are low compared to other common oxalate containing vegetables $[3,4]$.

\begin{tabular}{|l|l|l|l|l|}
\hline Mushroom Samples & Range( $\mathbf{n})$ & Total oxalates & Soluble oxalates & Insoluble Oxalatesa \\
\hline H. erinaceus & 3 & $45 \pm 3.2$ & ND & ND \\
\hline S. crispa & 3 & $52 \pm 1.6$ & ND & ND \\
\hline C. cibarius & 3 & $96 \pm 1.4$ & $48 \pm 2.6$ & 48 \\
\hline
\end{tabular}


Citation: Nile SH and Park SW (2014) Bioavailability Analysis of Oxalate and Mineral Content in Selected Edible Mushrooms. J Nutr Disorders Ther 4: 138. doi:10.4172/2161-0509.1000138

Page 4 of 6

\begin{tabular}{|c|c|c|c|c|}
\hline L. squarrulosus & 3 & $62 \pm 1.3$ & $45 \pm 1.4$ & 17 \\
\hline H. repandum & 3 & $73 \pm 1.8$ & $52 \pm 1.1$ & 21 \\
\hline P. sajorcaju & 3 & $73 \pm 2.3$ & $52 \pm 2.2$ & 21 \\
\hline G. arinarius & 3 & $58 \pm 2.6$ & ND & ND \\
\hline L. sanguifluus & 3 & $74 \pm 1.1$ & $42 \pm 2.1$ & 32 \\
\hline A. polytricha & 3 & $92 \pm 2.8$ & $44 \pm 3.1$ & 48 \\
\hline R. brevepis & 3 & $89 \pm 3.7$ & $35 \pm 1.6$ & 44 \\
\hline M. conica & 3 & $104 \pm 4.2$ & $60 \pm 2.7$ & 40 \\
\hline B. edulis & 3 & $48 \pm 2.1$ & ND & ND \\
\hline L. deliciosus & 3 & $74 \pm 1.4$ & $34 \pm 2.4$ & 40 \\
\hline C. clavatus & 3 & $76 \pm 3.3$ & $37 \pm 1.4$ & 39 \\
\hline H. crispa & 3 & $68 \pm 4.2$ & ND & ND \\
\hline A. bisporus & 3 & $69 \pm 1.9$ & $49 \pm 2.4$ & 20 \\
\hline P. djamor & 3 & $84 \pm 2.6$ & $49 \pm 3.1$ & 35 \\
\hline G. lucidum & 3 & $54 \pm 1.6$ & ND & ND \\
\hline P. rimosus & 3 & $94 \pm 2.6$ & $51 \pm 1.9$ & 43 \\
\hline P. florida & 3 & $89 \pm 3.4$ & $65 \pm 3.1$ & 24 \\
\hline
\end{tabular}

Table 2: Total, soluble, and insoluble oxalate contents of twenty different edible mushrooms (mg/100 g DW \pm SD)

\begin{tabular}{|c|c|c|c|c|c|}
\hline Mushroom Samples & Range(n) & $\mathrm{Ca}$ & $\mathbf{P}$ & $\mathbf{K}$ & Mg \\
\hline H. erinaceus & 3 & $1.35 \pm 0.21$ & $3.62 \pm 0.61$ & $22.1 \pm 1.2$ & $1.92 \pm 0.11$ \\
\hline S. crispa & 3 & $2.56 \pm 0.15$ & $2.64 \pm 0.45$ & $23.5 \pm 2.3$ & $1.81 \pm 0.41$ \\
\hline C. cibarius & 3 & $5.36 \pm 0.19$ & $1.22 \pm 0.02$ & $21.3 \pm 1.4$ & $1.19 \pm 0.15$ \\
\hline L. squarrulosus & 3 & $3.56 \pm 0.11$ & $2.71 \pm 0.18$ & $20.1 \pm 1.3$ & $4.71 \pm 0.28$ \\
\hline H. repandum & 3 & $5.89 \pm 0.32$ & $2.98 \pm 0.34$ & $17.6 \pm 2.1$ & $1.90 \pm 0.34$ \\
\hline P. sajorcaju & 3 & $4.65 \pm 0.13$ & $3.82 \pm 0.51$ & $22.5 \pm 1.4$ & $1.54 \pm 0.44$ \\
\hline G. arinarius & 3 & $2.88 \pm 0.23$ & $2.51 \pm 0.31$ & $18.6 \pm 3.1$ & $1.39 \pm 0.30$ \\
\hline L. sanguifluus & 3 & $6.56 \pm 0.12$ & $3.45 \pm 0.47$ & $24.2 \pm 1.6$ & $1.65 \pm 0.15$ \\
\hline A. polytricha & 3 & $2.80 \pm 0.26$ & $1.84 \pm 0.12$ & $18.6 \pm 2.3$ & $2.57 \pm 0.11$ \\
\hline R. brevepis & 3 & $1.64 \pm 0.14$ & $2.55 \pm 0.70$ & $21.5 \pm 2.4$ & $2.15 \pm 0.23$ \\
\hline M. conica & 3 & $12.56 \pm 0.41$ & $3.57 \pm 0.40$ & $15.4 \pm 1.6$ & $1.23 \pm 0.19$ \\
\hline B. edulis & 3 & $1.35 \pm 0.11$ & $3.25 \pm 0.19$ & $20.1 \pm 1.9$ & $2.06 \pm 0.32$ \\
\hline L. deliciosus & 3 & $2.57 \pm 0.30$ & $3.61 \pm 0.13$ & $25.4 \pm 2.1$ & $1.23 \pm 0.41$ \\
\hline C. clavatus & 3 & $1.36 \pm 0.23$ & $3.12 \pm 1.91$ & $15.8 \pm 1.8$ & $2.38 \pm 0.11$ \\
\hline H. crispa & 3 & $3.51 \pm 0.12$ & $2.85 \pm 0.23$ & $20.1 \pm 2.0$ & $2.47 \pm 0.32$ \\
\hline
\end{tabular}




\begin{tabular}{|l|l|l|l|l|l|}
\hline A. bisporus & 3 & $3.75 \pm 0.51$ & $2.45 \pm 0.11$ & $19.5 \pm 1.9$ & $4.54 \pm 0.21$ \\
\hline P. djamor & 3 & $2.56 \pm 0.16$ & $3.02 \pm 0.45$ & $22.3 \pm 1.4$ & $1.38 \pm 0.18$ \\
\hline G. lucidum & 3 & $4.15 \pm 0.12$ & $1.95 \pm 0.36$ & $24.6 \pm 2.5$ & $1.70 \pm 0.24$ \\
\hline P. rimosus & 3 & $7.52 \pm 0.21$ & $3.12 \pm 0.72$ & $18.6 \pm 1.3$ & $1.37 \pm 0.31$ \\
\hline P. florida & 3 & $3.56 \pm 0.14$ & $3.11 \pm 0.55$ & $20.4 \pm 1.1$ & $3.28 \pm 0.17$ \\
\hline n: Number of samples analyzed & & & \\
\hline
\end{tabular}

Table 3: Calcium (Ca), Phosphorus (P), Potassium (K), and Magnesium (Mg) contents of twenty different edible mushrooms (mg/g DW \pm SEM)

\section{Conclusions}

In conclusion, based on our results it was concluded that, the availability of current data on total, soluble, insoluble oxalate and mineral content edible mushrooms were insufficient and needs further research before getting any conclusion about them. Edible mushrooms, which are part of many cuisines in world, are found to contain oxalates and minerals. However, the oxalate contents of edible mushrooms in different locations may vary depending on the species, cultivars, climates, processing, and extraction methods. Some mushrooms, including Morchella conica, Cantharellus cibarius, Phellinus rimosus and Auricularia polytricha were found to have most of their oxalates in the soluble form and, therefore, should be avoided by people with hyperoxaluria or a tendency to form kidney stones. The virtual quantity of soluble oxalate in fresh mushrooms in a reasonable diet portion could be considered, which can be calculated by converting the DW contents to fresh ones. The values can be used to refer to those recommended by the American Dietetic Association as an example. Overall, the percentage of soluble oxalate content of the selected mushrooms ranged from 34 to $65 \%$ of the total oxalate content which suggests that, the selected edible mushrooms presents no risk to people liable to kidney stone formation while other foods like some spices and vegetables can supply significant amounts of soluble oxalates and minerals; therefore should be used in moderation as good vegetable, which might be important for human nutrition.

\section{Acknowledgement}

This work was supported by Konkuk, Smart Research Professor Program-2014, Konkuk University, South Korea.

\section{References}

1. Breene W (1991) Nutritional and medicinal value of specialty mushrooms. J Food Protect 53: 883-894.

2. Mattila P, Suonpää K, Piironen V (2000) Functional properties of edible mushrooms. Nutrition 16: 694-696.

3. Mallavadhani U, Sudhakar A, Sathyanarayana KVS, Mahapatra A, Li W, et al. (2006) Chemical and analytical screening of some edible mushrooms. Food Chem 95: 58-64.

4. Savage GP, Vanhanen L, Mason SM, Ross AB (2000) Effect of cooking on the soluble and insoluble oxalate content of some New Zealand foods. J Food Comp Analy 13: 201-206.

5. Radek M, Savage GP (2008) Oxalates in some Indian green leafy vegetables. Int J Food SciNutr 59: 246-260.

6. Arnott HJ, Whitney KD (1984) Calcium oxalate crystal formation in a species of Hypoderma (Basidiomycetes). In Proceedings of the 42nd Annual Meeting of the Electron Microbiology Society of America ed. GW Bailey San Francisco CA, San Francisco Press, p. 320.
7. Noonan SC, Savage GP (1999) Oxalate content of foods and its effect on humans. Asia Pac J ClinNutr 8: 64-74.

8. Savage GP, Martensson L (2010) Comparison of the estimates of the oxalate content of taro leaves and corms and a selection of Indian vegetables following hot water, hot acid and in vitro extraction methods. J Food Comp Analy 23: 113-117.

9. Simpson TS, Savage GP, Sherlock R, Vanhanen LP (2009) Oxalate content of silver beet leaves (Beta vulgaris var. cicla) at different stages of maturation and the effect of cooking with different milk sources. J Agric Food Chem 57: 10804-10808.

10. Tang M, Larson-Meyer DE, Liebman M (2008) Effect of cinnamon and turmeric on urinary oxalate excretion, plasma lipids, and plasma glucose in healthy subjects. Am J ClinNutr 87: 1262-1267.

11. Holmes RP, Goodman HO, Assimos DG (2001) Contribution of dietary oxalate to urinary oxalate excretion. Kidney Int 59: 270-276.

12. Griffin DG (2004) A review of the heritability of idiopathic nephrolithiasis. J ClinPathol 57: 793-796.

13. Brogren M, Savage GP (2003) Bioavailability of soluble oxalate from spinach eaten with and without milk products. Asia Pac J ClinNutr 12: 219-224.

14. Puttaraju NG, Venkateshaiah SU, Dharmesh SM, Urs SM, Somasundaram R (2006) Antioxidant activity of indigenous edible mushrooms. J Agric Food Chem 54: 9764-9772.

15. Rittera MMC, Savage GP (2007) Soluble and insoluble oxalate content of nuts. J Food Comp Analy 20: 169-174.

16. Nile SH, Khobragade CN (2009) Determination of nutritive value and mineral elements of some important medicinal plants from western part of India. J Medicinal Plants 8: 79-88.

17. Okombo J, Liebman M (2010) Oxalate content of selected breads and crackers. J Food Comp Analy 23: 118-121.

18. Jayaraman J (2011) Laboratory manual in Biochemistry, New age International (p). Ltd 2nd edition, pp.75-88.

19. Massey LK, Palmer RG, Horner HT (2001) Oxalate content of soybean seeds (Glycine max: Leguminosae), soyfoods, and other edible legumes. J Agric Food Chem 49: 4262-4266.

20. Mandadi K, Ramirez M, Jayaprakasha GK, Faraji B, Lihono M, et al. (2009) Citrus bioactive compounds improve bone quality and plasma antioxidant activity in orchidectomized rats. Phytomedicine 16: 513-520.

21. Agrahar-Murugkar D, Subbulakshmi G (2005) Nutritional value of edible wild mushrooms collected from the Khasi hills of Meghalaya. Food Chem 89: 599-603.

22. Adejumo TO, Awosanya OB (2005) Proximate and mineral composition of four edible mushroom species from South Western Nigeria. African J Biotech 4: 1084-1088.

23. Kumar Sharma S, Deb P, Shukla R, Prabaharan T, Shyam A (2011) Compact pulse forming line using barium titanate ceramic material. Rev SciInstrum 82: 115102 .

24. Massey LK, Kynast-Gales SA (1998) Substituting milk for apple juice does not increase kidney stone risk in most normocalciuric adults who form calcium oxalate stones. J Am Diet Assoc 98: 303-308. 
Citation: Nile SH and Park SW (2014) Bioavailability Analysis of Oxalate and Mineral Content in Selected Edible Mushrooms. J Nutr Disorders Ther 4: 138. doi:10.4172/2161-0509.1000138

Page 6 of 6

25. Heaney RP, Weaver CM (1989) Oxalate: effect on calcium absorbability. Am J ClinNutr 50: 830-832.

26. Hanes DA, Weaver CM, Heaney RP, Wastney M (1999) Absorption of calcium oxalate does not require dissociation in rats. J Nutr 129: 170-173.

27. Ohkawa H (1985) Gas chromatographic determination of oxalic acid in foods. J Assoc Off Anal Chem 68: 108-111.
28. Holmes RP, Goodman HO, Assimos DG (1995) Dietary oxalate and its intestinal absorption. Scanning Microsc 9: 1109-1118.

29. American Dietetic Association (2005) Urolithiasis/urinary stones. In, ADA Nutrition Care Manual. Chicago IL. USA, 483-486.

30. Chai W, Liebman M (2005) Effect of different cooking methods on vegetable oxalate content. J Agric Food Chem 53: 3027-3030. 